\title{
EFFECT OF ENERGY DISTRIBUTION ON THE EFFICIENCY OF AN ALL-WHEEL DRIVE ELECTRIC VEHICLE
} POWERTRAIN

\section{ADAM BARÁK}

Josef Božek Vehicle Centre for Sustainable Mobility Technická 4, Prague 6, Czech Republic, 16607

Tel.: +420 224351 827, E-mail: adam.barak@fs.cvut.cz

\section{SHRNUTí}

Článek popisuje simulaci elektrického vozidla s pohonem všech kol včetně implementace jednoduché optimalizační funkce pro určení optimálního rozložení výkonů mezi nápravy s ohledem na minimální ztráty v pohonném řetězci. Model zkoumaného elektrického vozidla je popsán vícehmotovou soustavou v programu Matlab/Simulink. Optimalizační funkce určuje v každém časovém kroku simulace poměr rozdělení výkonu mezi motorem na přední a motorem na zadní nápravě tak, aby celkový ztrátový výkon obou motorů byl minimální. V článku je na príkladu simulace jízdy vozidla v NEDC ukázán př́nos optimalizace rozdělení výkonů mezi jednotlivými elektromotory pro různá uspořádání pohonného řetězce.

\section{KLIČCVÁ SLOVA: ELEKTRICKÉ VOZIDLO, TRAKČNII MOTOR, ÚČINNOST, JÍZDNÍ CYKLUS, SIMULACE}

\section{ABSTRACT}

The paper describes a multi body simulation model of an all-wheel drive electric vehicle containing a simple embedded optimization tool that determines the optimal power load distribution ratio with respect to energy consumption between the vehicle front and rear axle. The vehicle simulation model is programmed in Matlab/Simulink. The embedded Matlab optimization function is based on an algorithm that searches for a distribution ratio with minimal power losses at both traction motors at each time step of the simulation. Various topologies are compared to show the potential of intelligent power flow control in electric vehicle powertrains.

KEYWORDS: ELECTRIC VEHICLE, TRACTION MOTOR, EFFICIENCY, DRIVING CYCLE, SIMULATION

\section{INTRODUCTION}

An electric vehicle (EV) uses one or more electric motors for its propulsion. The source of the electricity may be an on-board storage device (battery, flywheel, capacitor, etc.), on-board electrical generator (combustion engine, fuel cell) or an external power generator. The general term EV covers battery (full) electric cars BEV (FEV), plug-in hybrids PHEV and range-extenders EREV, scooters, motorcycles, trains, boats, bicycles etc. However, in this article EV refers only to the group of FEV electric cars.

EVs powered by on-board batteries are expected to become common place over the next one to two decades. Almost all major car manufacturers have already presented an EV concept. Some of them are already selling EVs in selected markets. The production of EVs receives significant support from governments due to the ever increasing demand for reducing the exhaust gas emissions and fossil fuel consumption of passenger car internal combustion engines (ICE).

The advantage of electric energy is that it can be generated from a wide range of sources, such as fossil fuels, nuclear power or renewable energy sources. It has to be mentioned that the wellto-wheel efficiency of EVs is strongly determined by the quality of the initial energy. However, on-board emissions of a battery powered EV are zero and the overall tank-to-wheel efficiency of an EV powertrain is much higher than the efficiency of an ICE or hybrid powertrain [1].

The greatest limiting factor of EVs is the battery. Although battery technology has made great progress during the last decade, batteries are still far away from being able to compete with fossil fuels in the measure of stored power to weight ratio (Figure 1). This leads to a significantly lower drive range of EVs compared to conventional vehicles [1].

Unless we assume that battery technology will improve dramatically over the next few years, it is necessary to further reduce power losses in the otherwise highly efficient electric powertrain. A lot of energy may be saved by the careful evaluation and optimization of the powertrain and the entire vehicle during the design stage. Further energy may be saved 


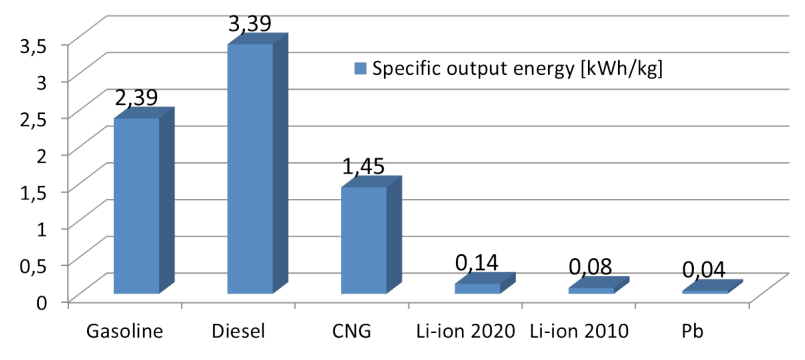

FIGURE 1: Specific output energy density for various energy sources (source: www.ertrac.org)

OBRÁZEK 1: Porovnání měrné hustoty uložené energie pro různé zásobníky

by intelligent control of energy flows in the powertrain. The target should be to regenerate as much energy by braking as possible and to run the traction motor (motors) with the lowest possible power losses.

The most efficient way to improve the powertrain and its control strategy in the design stage is the simulation approach. This article describes the capabilities of a self-designed powertrain simulation tool to evaluate the influence of particular powertrain components and control strategies on the overall powertrain efficiency and energy consumption. The simulation tool (RideSim [2],[3]) is in fact a library of custom Matlab/ Simulink blocks that mathematically represents powertrain components with a multi body simulation (MBS) approach. The RideSim library is capable of covering various conventional and alternative powertrain layouts. This article demonstrates the use of RideSim to optimize the control strategy of an allwheel drive electric powertrain with two traction motors.

\section{STATE OF THE ART}

An EV powertrain is in general less complicated than the ICE powertrain. It generally consists of a battery (or other energy source), one or more traction motors, gearboxes with fixed or variable gear ratio, differentials, clutches and wheels. The EV powertrain may be two-wheel drive or all-wheel drive. Twowheel drive powertrains are cheaper, but do not offer the possibility of recuperating the maximum amount of energy during regenerative braking, because it is usually not possible to efficiently brake with only one axle. The all-wheel drive layout has the advantage of optimal traction during acceleration and braking, and offers the possibility of using two different motor types or sizes and efficiently distributing the power between them. A smaller motor at the front axle might be used for lower power demands, whilst the bigger motor accelerates the vehicle and runs the vehicle at higher loads.

The small size of the motors makes it possible to run each wheel with a separate motor and use the benefits of torque vectoring. However, this layout decreases the ride comfort due to the increased unsprung mass and its efficiency is also poor.

\subsection{BATTERIES}

Batteries are currently the most expensive and also the weakest part of an EV. There are several battery types that might be used in EV powertrains. This section gives basic information about the three most commonly used battery types in EVs [4].

Early powertrains used heavy lead-acid batteries due to their low cost, mature technology and high availability. The disadvantage of lead acid batteries is that they should not be discharged below $50 \%$ of their capacity or their lifetime quickly decreases. Their weight is also a limiting factor for future EVs (30-40 Wh/kg).

Nickel metal hydride (NiMH) batteries are also considered to be a mature technology. NiMH offer higher energy density (30-80 Wh/kg) compared to lead acid at the cost of lower charging/ discharging efficiencies. Further disadvantages are high self-discharge and poor performance in cold conditions. Lithium-ion batteries are widely used in the new generation of EVs. Their biggest advantages are high energy density and the absence of memory effect. On the other hand, lithiumion batteries suffer from short cycle lives and more significant degradation with age compared to other battery types.

\subsection{ELECTRIC MOTORS}

Electric motors offer a much better torque over rpm characteristic for vehicle propulsion in comparison to ICE. The shape of their full load curve allows the motor to run with a constant gearbox ratio without the use of a clutch. However, multi ratio gearboxes might also be used in EV powertrains to optimize the operating point position over the whole operating range of the vehicle. This chapter describes the elementary differences between asynchronous (ASM) and synchronous (SM) motors that are relevant to this article. Both ASMs and SMs need a power electronic for their control. This power electronic is also a source of additional power losses that are speed and load dependent.

An ASM is powered with AC current. The stator of an induction motor consists of poles carrying supply current to induce a magnetic field that penetrates the rotor. There are several possible designs of rotor, but the most common is the squirrel cage rotor made up of skewed bars of copper or aluminum that span the length of the rotor. Its speed is controlled by the frequency of the supply current that powers the stator and creates a rotating magnetic field. The rotor has windings in the form of closed loops of wire. Currents in the rotor windings are induced by the rotating magnetic flux in the stator in a manner similar 


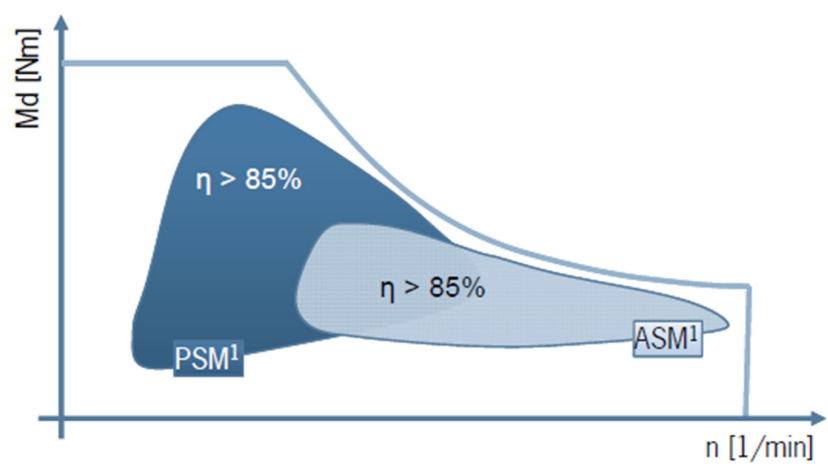

FIGURE 2: Typical position of best efficiency areas of an ASM and PSM OBRÁZEK 2: Typická poloha oblastí nejvyšší účinnosti u ASM a PSM

to currents induced in a transformer's secondary windings. The magnetic field generated in the rotor by these currents pushes against the stator field. The rotor rotates in the direction of the rotating stator magnetic field to minimize the relative speed between rotor and stator magnetic fields. Slip is the rotation rate of the magnetic field relative to the rotor, divided by the absolute rotation rate of the stator magnetic field. Slip determines the torque of the engine and is minimal at low load.

An ASM offers a more mature and cheaper technology compared to a SM. The overall efficiency of an ASM is lower than for a SM, especially at low speeds. The ASM rotor runs with zero slip during drag operation (zero load demand) and thus only a minimal current is induced due to the friction. The ASM power losses are therefore significantly smaller in drag mode compared to a SM.

A SM has the same stator design as an ASM. The rotor of a SM for most common EV applications consists of permanent magnets that are embedded in the solid steel rotor to create a constant magnetic field. This type of SM is called a permanent magnet synchronous motor (PSM). The rotor turns at the same rate as the stator magnetic field and thus runs with zero slip. In comparison with an ASM, a PSM offers higher efficiency over a major part of its operating range at the cost of higher power losses during motored operation. PSMs are therefore often connected with a clutch to the rest of the powertrain in order to eliminate these motoring losses. Further disadvantages of PSMs are higher cost and limited resources of permanent magnet materials. A comparison of the best efficiency areas of PSMs and ASMs is shown in Figure 2.

\section{SIMULATION TOOL}

Simulation models can generally be performed with different scopes and depths of accuracy. Simulation tools including mathematical modules for lateral and longitudinal dynamics have the highest level of physicality. On the other hand,

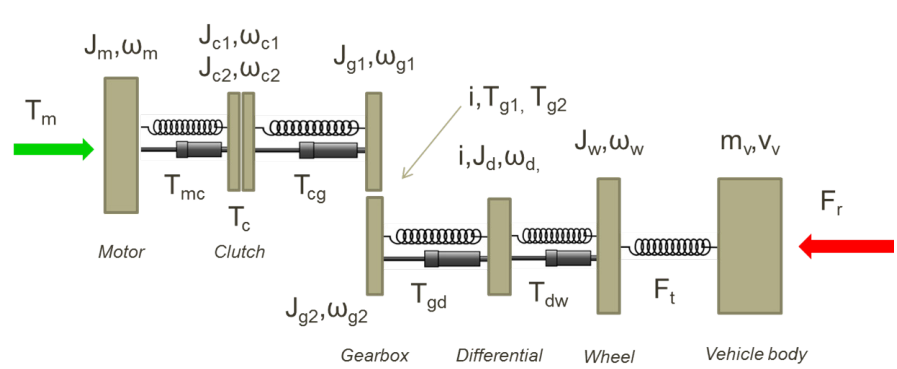

FIGURE 3: MBS EV driveline model

OBRÁZEK 3: Více-hmotový model pohonného řetězce elektrického vozidla

more complex models lead to longer computational time, higher code complexity and more simulation input data are needed. For reasons mentioned above, a model including only the longitudinal vehicle dynamics is used in this case. The model is intended to be used for calculation of system forces/torques, system states of motion (velocities, positions) and overall energy consumption during a vehicle ride in a predefined cycle, such as the NEDC or Artemis.

The simulation tool is built up in Matlab/Simulink of custom library blocks that represent particular powertrain components. It mathematically describes the behavior of the complete vehicle by the multi body system (MBS) approach. The MBS approach was chosen to describe the system for its relatively low computational time. Driveline components are modeled with rigid bodies linked with elements like springs and dampers. Distributed system properties such as mass, inertia, stiffness and damping are concentrated on mass elements (mass, inertia) and link elements (stiffness, damping). The system is then mathematically described with $\mathrm{n}$ differential equations ( $\mathrm{n}$ degrees of freedom) that are solved by numeric integration algorithms in the time domain using Matlab/Simulink solvers.

The basic function of the simulation tool will be described using the example of a powertrain that consists of motor, clutch, gearbox, differential, driveshaft, wheel and vehicle body. Most of the EV topologies may be simulated by combining these blocks.

\subsection{POWERTRAIN}

Each driveline shaft is modeled as a set of two constant inertias connected with a spring-damper element (Figure 3) [5].

Symbols used in Figure 3 are J (inertia), w (angular velocity), $\mathrm{T}$ (torque), $\mathrm{F}$ (force), $\mathrm{m}$ (mass), $\mathrm{v}$ (velocity). The meaning of symbol indexes is clear from Figure 3.

The dynamics of the system in Figure 3 is described by a set of equations (1) in accordance with Newton's law [5]: 


$$
\begin{aligned}
& J_{m} \dot{\omega}_{m}=T_{m}-T_{m c} \\
& J_{c 1} \dot{\omega}_{c 1}=T_{m c}-T_{c} \\
& J_{c 2} \dot{\omega}_{c 2}=T_{c}-T_{c g} \\
& J_{g 1} \dot{\omega}_{g 1}=T_{c g}-T_{g 1} \\
& J_{g 2} \dot{\omega}_{g 2}=T_{g 2}-T_{g d} \\
& J_{d} \dot{\omega}_{d}=T_{g d}-T_{d w} \\
& J_{w} \dot{\omega}_{w}=T_{d w}-F_{t} r_{w} \\
& m_{v} \dot{v}_{v}=F_{t}-F_{r}
\end{aligned}
$$

Where:

$$
\begin{aligned}
& T_{e c}, T_{c g}, T_{g d}, T_{d w}: \\
& T_{x y}=k_{x y} \Theta_{x y}+b_{x y} \omega_{x y} \\
& \dot{\Theta}_{x y}=\omega_{x y}=\omega_{x}-\omega_{y}
\end{aligned}
$$

\subsection{TRACTION MOTOR}

The traction motor is simplified to an ideal torque generator acting on a constant inertia that is connected via a rotor shaft to the clutch disk. The engine torque is limited by the full load curves for both motor and generator mode. Full load curves are realized by a look-up function that assigns the maximum motor or generator torque to the actual value of engine speed. Look up tables are also used to determine the power losses (motor efficiency) at specified speed and torque. The electrical power needed to run the motor is then calculated as the sum of mechanical power and actual power loss (3).

$$
P_{e l}=P_{\text {mech }}+P_{\text {loss }}=T_{m} \times \omega_{m}+P_{\text {loss }}
$$

The generator mode is calculated accordingly. The resulting motor efficiency is (4):

$$
\eta_{m}=\frac{P_{m e c h}}{P_{e l}}
$$

The motor power loss look-up tables might also be modified to efficiency look-up tables, but this results in complications with determination of power losses along the zero torque line.

\subsection{CLUTCH}

The clutch model is based on the Matlab demo example. However, it had to be significantly modified to fulfill the model demands. The clutch model assumes a stick-slip friction model. Different equations for clutch torque are used with locked (5) and unlocked clutch (6).

In the case of locked clutch, where $\omega_{c 1}=\omega_{c 2} \wedge|T d| \leq T_{c M}\left(F_{N}\right)[5]$ :

$$
T_{c}=\frac{J_{c 1} J_{c 2}}{J_{c 1}+J_{c 2}}\left(\frac{T_{m c}}{J_{c 1}}+\frac{T_{c g}}{J_{c 2}}\right)
$$

Otherwise [5]:

$$
T_{c}=T_{c M}\left(F_{N}\right) \times \operatorname{sign}\left(\omega_{c 1}-\omega_{c 2}\right)
$$

$T_{c M}\left(F_{N}\right)$ is the maximum transmissible torque and depends on the axial force that is applied to the clutch plate. The clutch is calculated as a coupled inertia when locked and as two inertias when unlocked. The state of the clutch thus changes the number of degrees of freedom of the system.

\subsection{BATTERY}

The Thevenin battery model is used to describe the battery behavior. It is an equivalent circuit battery model that simplifies the battery processes to a simple electronic circuit (Figure 4). It uses a capacitor to simulate the capacity $C$ of the battery and resistors $\mathrm{R}$ to simulate the internal resistance of the battery.

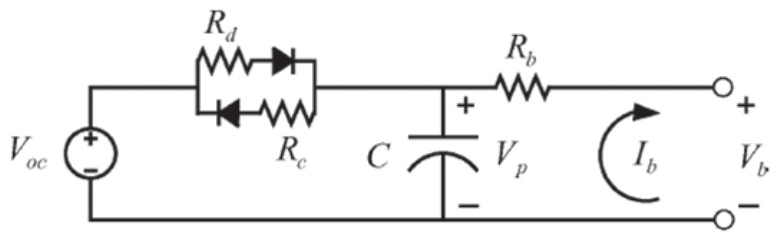

FIGURE 4: Equivalent circuit battery model- Thevenin OBRÁZEK 5: Ekvivalentní elektrické schéma Theveninova modelu baterie

The following equations describe the battery according to the Thevenin model [6]:

Discharging (7):

$$
\dot{V}_{p}=-V_{p} \frac{1}{R_{d} C}+V_{O C} \frac{1}{R_{d} C}-I_{b} \frac{1}{C}
$$


Charging (8):

$$
\dot{V}_{p}=-V_{p} \frac{1}{R_{c} C}+V_{O C} \frac{1}{R_{c} C}-I_{b} \frac{1}{C}
$$

Where the battery current $I_{b}$ is (9):

$$
I_{b}=\frac{V_{p}-V_{O C}}{R_{b}}
$$

All parameters may be entered as constants or as a function to better describe battery performance in relation to state of charge, rate of charge/discharge or temperature. Data must be measured or supplied by the battery manufacturers. The battery model also contains a simplified thermal model for a rough prediction of battery temperatures under load.

\subsection{CONTROL}

A simple driver model based on a PID controller is sufficient to precisely follow the NEDC demands. The demanded torque signal is addressed either to a single motor or divided between two power units. If the demanded torque exceeds the full throttle curve, then it is cut and the motor provides only the full throttle curve torque. The ratio of power load between front and rear motor can be either constant or may vary according to actual power demands.

Simple logic is used to lock and unlock the clutch (if the clutch is included in the model). Usually the clutch will be opened during the motoring of PSM to eliminate its high losses at zero torque. Thus the clutch is opened if a zero torque demand is detected above a certain vehicle velocity at the corresponding motor.

The general idea of effective power flow control between two or more motors is to distribute the power load between motors at a ratio that minimizes the total power losses. This approach
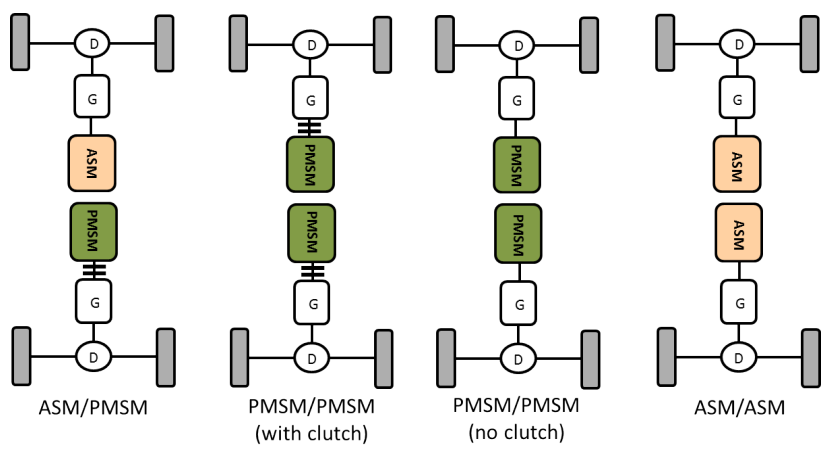

FIGURE 5: Overview of investigated EV layouts OBRÁZEK 5: Přehled zkoumaných pohonných řetězců

is effective if two or more motors of different type and/or power are used in one powertrain. The following considerations are made for an all-wheel drive powertrain run by two motors.

An embedded Matlab function for determination of the best power load distribution ratio is implemented in the simulation tool. This control function runs at each simulation time step and in a typical "for loop" interpolates the power loss look-up tables of both motors over a predefined range of load distribution ratios $(0,10,20 \ldots 100 \%$ at the rear axle, the rest on the front axle). The input for the interpolation is the demanded power defined in the driver module and the output is an array of power losses for the particular motor at actual speed and various loads. Power losses of both motors are summed together and these summed power losses are then compared among each other. The function searches the power load distribution with minimal losses and applies this distribution to the simulation tool at the current time step. The interpolated power loss for unloaded motor is automatically overwritten to zero in the case of a powertrain with PSM that might be decoupled by a clutch. The optimization process fully respects the full load curves of the motors and does not violate them.

The function may also run "offline". In this mode the driving cycle power demands are calculated with a $50-50 \%$ load

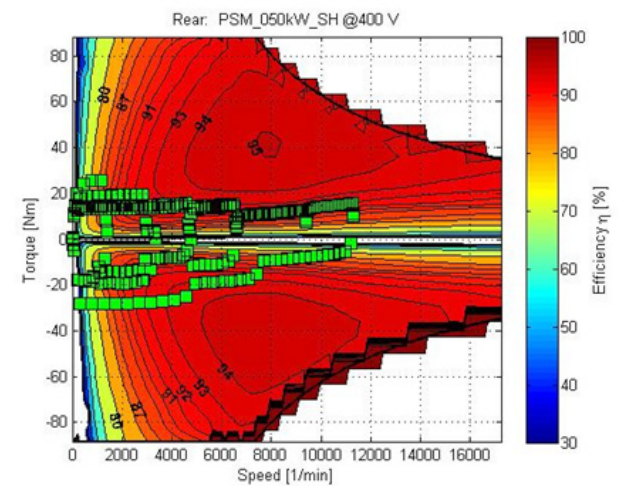



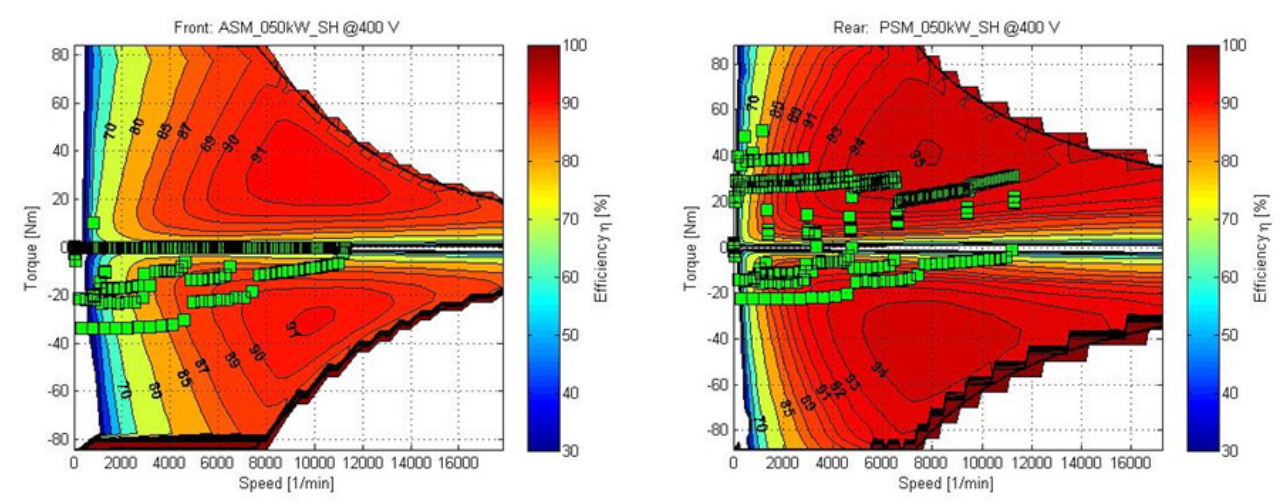

FIGURE 7: ASM/PSM optimized OBRÁZEK 7: ASM/PSM s optimalizací
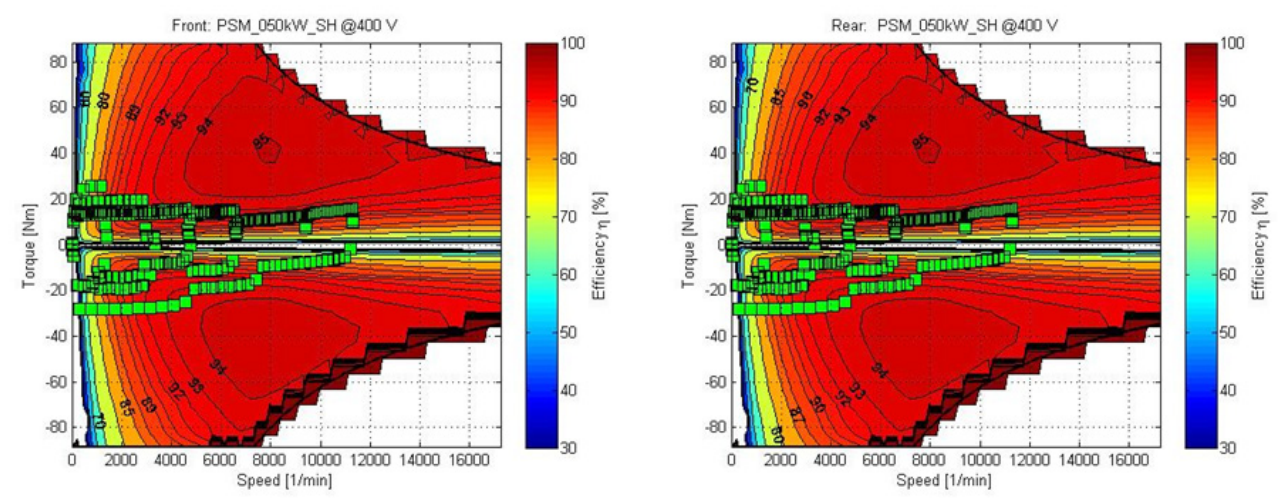

FIGURE 8: PSM/PSM not optimized

OBRÁZEK 8: PSM/PSM bez optimalizace

distribution. The power at both motors is then summed and by this optimization function redistributed to the motors to achieve minimal possible losses. The offline mode is good for a quick comparison of total energy losses in various motors over a driving cycle. The prerequisites are that the vehicle parameters (weight, resistances, etc.) remain constant as well as the driving cycle.

\section{RESULTS}

The optimization of power load distribution was performed on an example of EV topology with all-wheel drive powered by two motors, one for each axle. Both motors are equipped with a constant gear ratio gearbox, and alternately equipped with a clutch and differential that splits the power equally to the wheels. The gear ratios are the same for front and rear axle and all motor combinations. The criterion for gear ratio selection was the top speed of the vehicle $200 \mathrm{~km} / \mathrm{h}$ at the maximum motor speed $18000 \mathrm{rpm}$.

Four possible combinations of motor types were considered (Figure 5): ASM/PSM, PSM/PSM with and without clutches, ASM/ASM. The set of plot results in the following section always contains a set of graphs for optimized and 50-50\% power load distribution. The graphs show the torque/rpm points in NEDC directly in efficiency maps of traction motors, thus it is obvious whether the motor mostly runs in a good or poor efficiency area. All motors were rated

at $50 \mathrm{~kW}$. Efficiency maps are scaled results of FEM simulations. Please note that the load distribution was not optimized in the negative torque area. The braking power was instead distributed $60 \%$ to the front axle and $40 \%$ to the rear axle to maintain vehicle stability during braking. All results were achieved with a virtual vehicle defined by the same parameters (weight, wheel radius, etc.).

\subsection{FRONT: ASM, REAR: PSM}

The comparison of optimized (Figure 7) and initial power load distribution (Figure 6) shows that the ASM motors have overall lower efficiency than the PSM. The ASM motor is used only for regenerative braking after the optimization, which shifts the operating point for the PSM toward the higher efficiency area. It would also be used for greater accelerations to support the PSM. The ASM does not have significant power losses at zero torque and thus does not have to be equipped with a clutch.

\subsection{FRONT: PSM, REAR: PSM}

The possibility of using a clutch to disconnect the unloaded PSM motor and thus reduce its losses was also evaluated in the case of EV topology with two PSMs (Figure 9). The rear motor is used only for accelerations in the optimized case with the clutch. The optimized case without a clutch (Figure 10) is identical with the 

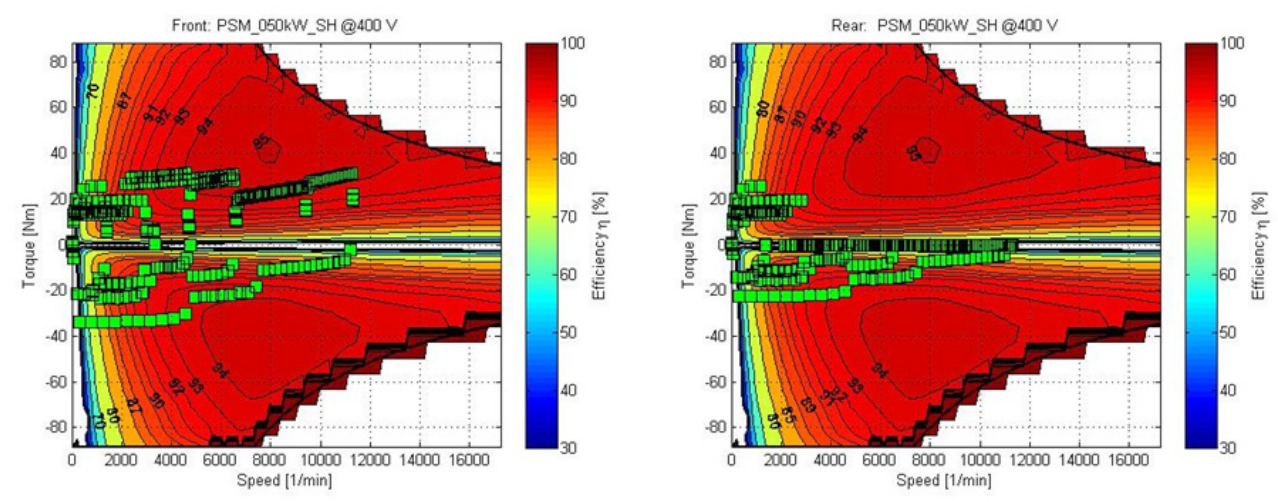

FIGURE 9: PSM/PSM optimized (with clutch)

OBRÁZEK 9: PSM/PSM s optimalizací (se spojkou)
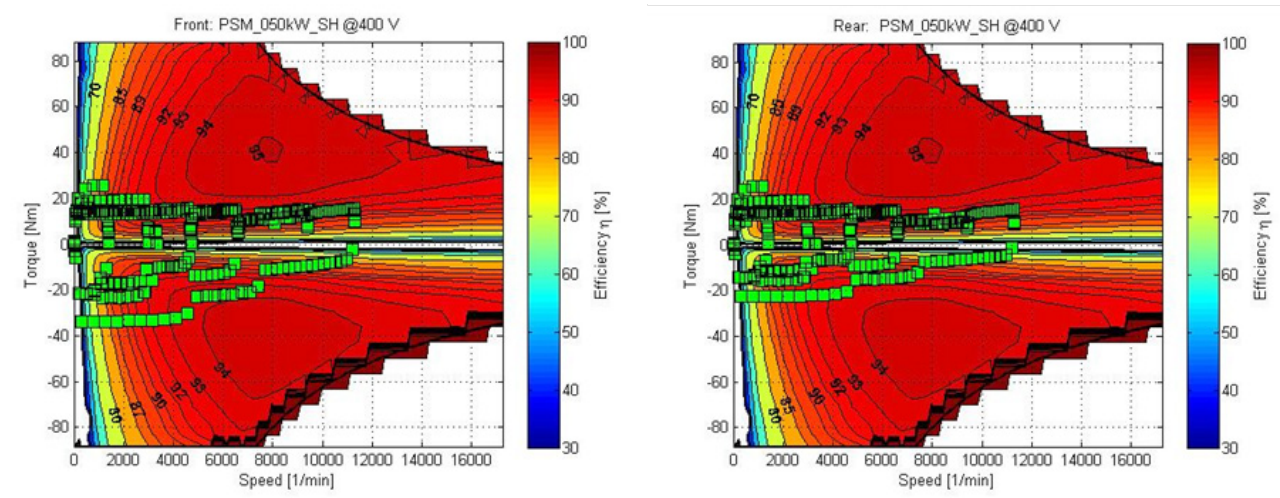

FIGURE 10: PSM/PSM optimized (no clutch)

OBRÁZEK 10: PSM/PSM s optimalizací (bez spojky)

initial $50 \%$ to $50 \%$ load distribution (Figure 8). It confirms the expectation that it brings no efficiency gain to distribute the power load unequally between two identical PSM motors with the same gear ratios.

\subsection{FRONT: ASM, REAR: ASM}

The optimized case (Figure 12) is proportionally very similar to the PSM/PSM case with a clutch. The resulting losses are bigger because of the poor overall efficiency of ASMs.

\subsection{COMPARISON OF MOTOR ENERGY LOSSES IN THE NEDC}

The green columns in Figure 13 give a comparison of relative energy losses at both traction motors in the NEDC for all topology cases. The relative potential of energy flow optimization compared to the particular base concept topologies is represented by the red columns. The optimized PSM/PSM topology with a clutch has the lowest energy losses. However, the optimized topology of ASM/ PSM would offer a good alternative choice for a cheaper price.

\section{CONCLUSION}

A dynamic model of an AWD electric vehicle was built from the library of custom MBS blocks designed in Matlab/ Simulink

environment and was coupled with a function that optimizes the power load distribution between front and rear axle. Various topologies were evaluated with initial $50-50 \%$ and optimized power load distribution in the NEDC. The results confirm that the use of an optimization function leads to lower power losses and better efficiency. The comparison of total energy losses in the NEDC shows the high efficiency of PSMs compared to ASMs, which is in good agreement with general experience.

Further work should be focused on comparison of topologies with motors of different rated powers, topologies with multiple gear ratio gearboxes and topologies with three or more traction motors. The acceleration and top speed performance of particular topologies should also be evaluated.

\section{ACKNOWLEDGEMENTS}

This research has been realized using the support of EU Regional Development Fund in OP R\&D for Innovations (OP VaVpl) and Ministry for Education, Czech Republic, project \# CZ.1.05/2.1.00/03.0125 - ED2.1.00/03.0125 Josef Božek Research Centre for Vehicles of Sustainable Mobility. This support is gratefully acknowledged. 

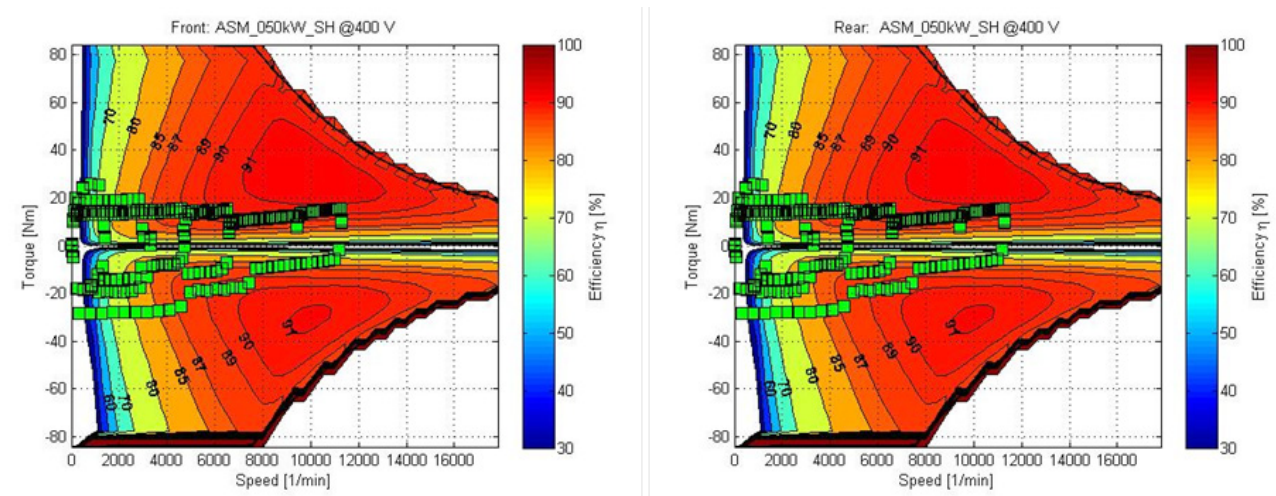

FIGURE 11: ASM/ASM not optimized

OBRÁZEK 11: ASM/ASM bez optimalizace
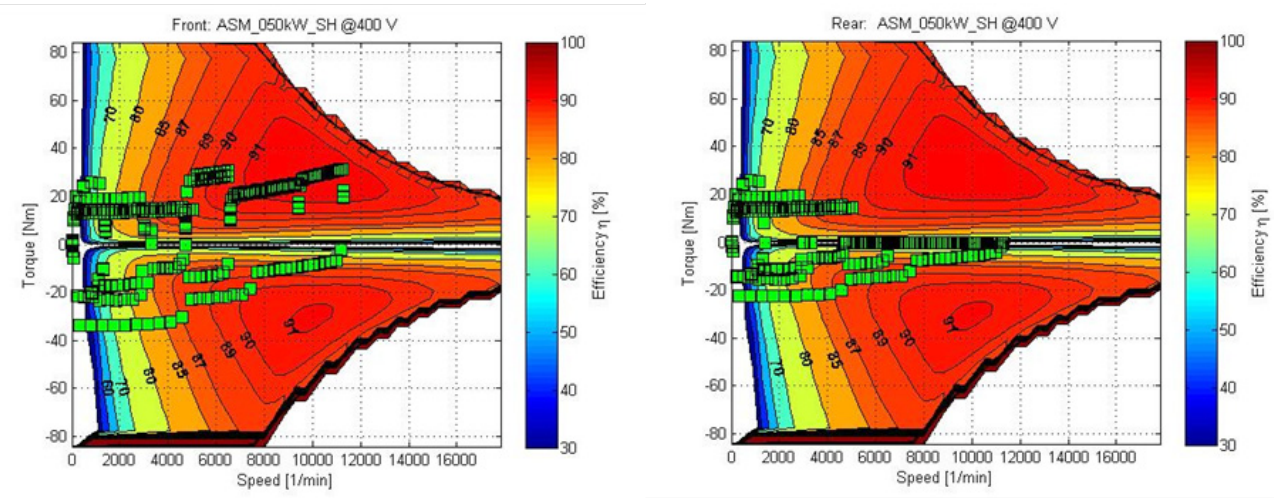

FIGURE 12: ASM/ASM optimized

OBRÁZEK 12: ASM/ASM s optimalizací

This work has been also supported within the framework of the grant number: SGS10/255/OHK2/3T/12. This support is gratefully acknowledged.

\section{REFERENCES}

[1] Barák A., Klír V., Macek J. (2010). Zhodnocení potenciálu elektrických vozidel pomocí tank to user analýzy,

Elektromobilita v silniční dopravě a 21. století, Praha, 2010

[2] Barák A., et al (2010). Powertrain Simulation Tool. MECCA - Journal of Middle European Construction and Design of Cars. 2010/3-4. p. 1 - 4. ISSN 1214-0821.

[3] Barák A., et al (2010). Model spotřeby hybridního vozidla v LabVIEW. AUTOMA - Časopis pro automatizační techniku. 2010/6.p. 52-53. ISSN 12-10-9592

[4] Čeřovský Z., et al (2002). Hybridní pohony automobilů a výzkumné pracoviště hybridních pohonů. [Online] 2002. http://www3.fs.cvut.cz/web/fileadmin/documents/12241BOZEK/publikace/2002/.

[5] Lucente G., et al (2005). Modelling of a car driveline for servo-actuated gear shift control, University of Bologna, 2005

[6] Chiasson J., (2005). Estimating the State of Charge of a Battery, IEEE Transactions on control system technology, Vol.13, 2005

FIGURE 13: Comparison of motor power loses of the investigated topologies

OBRÁZEK 13: Porovnání ztrát v elektrických pohonech zkoumaných uspořádání pohonného řetězce 